\title{
Avaliação do estado nutricional e da caquexia em pacientes diagnosticados com carcinoma epidermoide de cabeça e pescoço tratados com intenção curativa com quimiorradiação
}

\author{
Evaluation of the nutritional status and cachexia in patients diagnosed with head and \\ neck squamous cell carcinoma treated with chemoradiation with curative intention
}

\section{Acadêmico: Eduardo Furquim Simão \\ Orientador: Gilberto de Castro Junior}

\begin{abstract}
Introdução: A caquexia pode estar presente após quimiorradioterapia (QRT) concomitante baseada em cisplatina em pacientes com carcinoma epidermoide (CEC) de cabeça e pescoço (CCP). Os objetivos do estudo foram: avaliar o estado nutricional e a prevalência e grau de caquexia nos pacientes com CCP em remissão; avaliar a performance da Avaliação Subjetiva Global Produzida pelo Paciente (ASG-PPP) como ferramenta de avaliação nutricional nesses pacientes.
\end{abstract}

Métodos: Estudo transversal e uni-institucional. Elegibilidade: pacientes com CEC de CCP tratados com QRT com intenção curativa e livres de doença por mais de dois anos. A caquexia foi diagnosticada a partir de duas definições, que incluíram, para o cálculo: perda de peso, índice de massa corpórea (IMC), redução da força muscular, fadiga, anorexia, baixo índice de massa magra, alterações bioquímicas.

Resultados: Houve predomínio do sexo masculino (74\%) e de tumor primário em orofaringe (45\%). O peso perdido durante o tratamento foi $6,35 \pm 4,9 \mathrm{~kg}$ em média e o recuperado, após o tratamento, foi 5,5 $58,6 \mathrm{~kg}$; $16,4 \%$ apresentaram IMC $<20 \mathrm{~kg} / \mathrm{m}^{2}$ no recrutamento. O critério proposto por Evans et al. resultou na prevalência de caquexia de 9,7\%, que alcança $37,1 \%$ se desconsiderarmos o critério de perda de peso. Segundo o critério adotado por Fearon et al, a prevalência foi $26,2 \%$, semelhante a de indivíduos moderadamente desnutridos segundo a ASG-PPP (21,6\%).

Conclusões: Devido à alta prevalência da caquexia e sua relação com a morbi-mortalidade nesses pacientes, diagnosticá-la precocemente é importante para que seja tratada e manejada adequadamente.

Palavras-chave: Caquexia; Sarcopenia; Neoplasias de cabeça e pescoço; Seguimentos; Radioterapia.

Introduction: Cachexia may be observed in head and neck squamous cell carcinoma (HNSCC) after cisplatin-based concurrent chemoradiation (CCR). The purpose was to evaluate the nutritional status and the prevalence and stage of cachexia in HNSCC patients (pts) treated with CCR and with no evidence of disease during, at least, 2 years; to evaluate the Patient-Generated Subjective Global Assessment (PG-SGA) as a tool of nutrition evaluation in these pts.

Methods: Cross-sectional and uniinstitutional study. Eligibility: HNSCC patients treated with CCR with curative intention and disease-free for at least 2 years. Cachexia was diagnosed using two different criteria, based on weight loss, body mass index (BMI), reduced muscle strength, fatigue, anorexia, low lean body mass and biochemical abnormalities.

Results: There was a predominance of male (74\%) and oropharynx as the primary site (45\%). During the CCR, mean weight loss was $6.35 \pm 4.9 \mathrm{~kg}$, then increased in the period between CCR and recruitment $(5.5 \pm 8.6 \mathrm{~kg}) .16 .4 \% \mathrm{had}$ a BMI $>20 \mathrm{~kg} /$ 
$\mathrm{m}^{2}$ at the time of recruitment. According to criteria by Evans et al., prevalence of cachexia was 9.7\%, although, excluding lost weight that had been recovered in the last year, the value increases to $37.1 \%$. According to criteria by Fearon et al., prevalence was $26.2 \%$, similar to the percentage of pts whose evaluation through PG-SGA indicated moderate malnutrition $(21.6 \%)$.

Conclusion: Due to its high prevalence and a possible relation to morbidity and mortality, cachexia must be early diagnosed and adequately treated in HNSCC pts after CCR.

Keywords: Cachexia; Sarcopenia; Head and neck neoplasms; Follow-up studies; Radiotherapy. 